\title{
CORRESPÒNDENCE
}

\section{AUREOMYCIN IN TRACHOMA}

To the Editorial Committee of the

BRITISH JourNal OF OPHTHALMOLOGY

DeAR SIRS-I think the paper published by A. J. Boase in the October, 1950, issue of the British Journal of Ophthalmology, regarding the treatment of trachoma by means of aureomycin, might give unwarranted hopes to those practising in heavily infected areas like ours. Boase has completely disregarded the secondary bacterial infection which is always the cause of severe clinical signs in trachoma. This secondary bacterial infection responds magically to the proper antibiotic or sulpha drugs whether locally or generally given. Our experience in this country, following the same steps as Dr. Boase's, is that aureomycin, locally or generally, is an effective antibiotic against secondary infection in trachoma, but not against the trachomatous virus. All our cases were controlled by Gram-stained smears from the conjunctiva for bacterial invasion, along with Giemsa-stained scrapes for inclusion bodies.

Yours faithfully,

IBRAHIM AHMED MOHAMED

Memorial Ophthalmic Laboratory, GizA, CAIRo, EgYPT. January 27, 1951.

Assistant Director, Memorial Ophthalmic Laboratory, Giza, Egypt.

\section{CONTACT LENS IN UNILATERAL APHAKIA}

To the Editorial Committee of the

BRITISH JouRnal OF OpHTHALMOLOGY

DeAR SIRs-I read Mr. Hirtenstein's article on contact lens in unilateral aphakia with great interest, because most of my cases of traumatic cataract were fitted with contact lenses.

Of over twenty cases corrected in this way during the last seven years, more than half are using their lens. They are, in particular, the young and middle-aged patients, whereas the older ones found the lens too difficult to get used to.

Among my series are five children aged between seven and thirteen.

25, High Petergate, YORK. January 29, 1951.

Yours faithfully,

J. A. Magnus 